Proc. Indian Acad. Sci. (Earth Planet. Sci.), Vol. 102, No. 4, December 1993, pp. 547-565.

(C) Printed in India.

\title{
The nature of the basement in the Archaean Dharwar craton of southern India and the age of the Peninsular Gneiss
}

\author{
K NAHA $^{1}$, R SRINIVASAN ${ }^{2}, K_{\text {GOPALAN }}^{2}$, G V C PANTULU ${ }^{2}$, \\ $M$ V SUBBA RAO ${ }^{2}$, A B VREVSKY $^{3}$ and YE S BOGOMOLOV ${ }^{3}$ \\ ${ }^{1}$ Department of Geology and Geophysics, Indian Institute of Technology, Kharagpur 721302 , \\ India \\ ${ }^{2}$ National Geophysical Research Institute, Uppal Road, Hyderabad 500007, India \\ ${ }^{3}$ Institute of Precambrian Geology and Geochronology, Makarova emb. 2, St. Petersberg \\ 199034, Russia
}

MS received 14 July 1993

\begin{abstract}
The Archaean Peninsular Gneiss of southern India is considered by a number of workers to be the basement upon which the Dharwar supracrustal rocks were deposited. However, the Peninsular Gneiss in its present state is a composite gneiss formed by synkinematic migmatization during successive episodes of folding $\left(\mathrm{DhF}_{1}, \mathrm{DhF}_{1}\right.$ and $\left.\mathrm{DhF}_{2}\right)$ that affected the Dharwar supracrustal rocks. An even earlier phase of migmatization and deformation $\left(\mathrm{DhF}_{*}\right)$ is evident from relict fabrics in small enclaves of gneissic tonalites and amphibolites within the Peninsular Gneiss. We consider these enclaves to represent the original basement for the Dharwar supracrustal rocks. Tonalitic pebbles in conglomerates of the Dharwar Supergroup confirm the inference that the supracrustal rocks were deposited on a gneissic basement.

Whole rock $\mathrm{Rb}-\mathrm{Sr}$ ages of gneisses showing only the $\mathrm{DhF}_{1}$ structures fall in the range of $3100-3200 \mathrm{Ma}$. Where the later deformation $\left(\mathrm{DhF}_{2}\right)$ has been associated with considerable recrystallization, the $\mathbf{R b}-\mathbf{S r}$ ages are between $2500 \mathrm{Ma}$ and $2700 \mathrm{Ma}$. Significantly, a new $\mathrm{Rb}-\mathrm{Sr}$ analysis of tonalitic gneiss pebbles in the Kaldurga conglomerate of the Dharwar sequence is consistent with an age of $\sim 2500 \mathrm{Ma}$ and not that of $3300 \mathrm{Ma}$ reported earlier by Venkatasubramanian and Narayanaswamy (1974). $\mathrm{Pb}-\mathrm{Pb}$ ages based on direct evaporation of detrital zircon grains from the metasedimentary rocks of the Dharwar sequence fall into two groups, 3300-3100 Ma, and 2800-3000 Ma. Stratigraphic, structural, textural and geochronologic data, therefore, indicate that the Peninsular Gneiss of the Dharwar craton evolved over a protracted period of time ranging from $>3300 \mathrm{Ma}$ to $2500 \mathrm{Ma}$.
\end{abstract}

Keywords. Archaean; Peninsular Gneiss; structural history; basement-cover problem; $\mathrm{Rb}-\mathrm{Sr}$ and Zircon Pb-isotope geochronology.

\section{Introduction}

The nature of the basement gneisses and their relationship with the Dharwar supracrustal rocks (figure 1) in the southern Indian Archaean terrane has long been debated (Foote 1886; Smeeth 1916; Rama Rao 1940; Pichamuthu 1982). There is a divergence of opinion as to whether there is more than one generation of gneisses as against more than one group of supracrustal rocks. Foote (1884) considered the graniticgranodioritic-tonalitic gneisses making up a major part of the Dharwar craton to be the basement ('Fundamental Gneiss') occurring in the cores of anticlines, with the supracrustal schists of the Dharwar System (now termed Supergroup) exposed in synclinal keels. Differing radically from this view, Smeeth (1916) took the Dharwar supracrustal belts to be older and affected by the gneisses, which he renamed the 


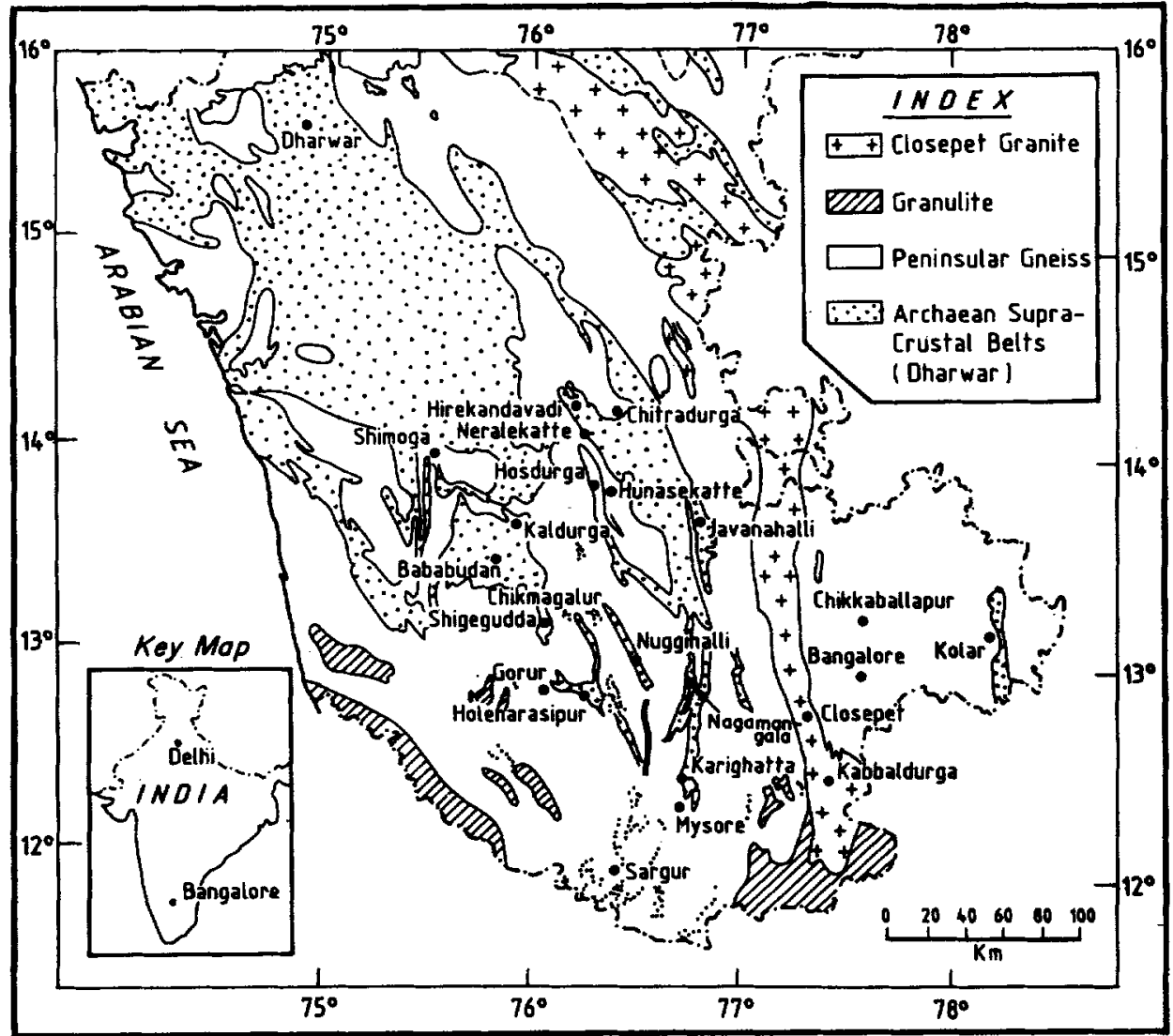

Figure 1. Geological map of the Archaean Dharwar craton, southern India.

Peninsutar Gneiss. Unlike Foote, Smeeth further held that the supracrustal rocks are wholly igneous in parentage.

In contrast to the views of both Foote and Smeeth, Rama Rao (1940) contended (a) that the Dharwar Supergroup comprises both sedimentary and igneous (mainly volcanic) rocks now metamorphosed to varying degrees, and (b) that the relation between the Peninsular Gneiss and the Dharwar schists is more complex than what either Foote or Smeeth thought. According to Rama Rao, the Peninsular Gneiss has evolved in several phases over a long period of time; an original 'granitic' basement was rejuvenated repeatedly so that the Peninsular Gneiss, as we see it now, is mainly younger than the Dharwar supracrustal rocks.

Smeeth divided the Dharwar 'System' into a lower Hornblendic Division and an upper Chloritic Division - a classification based on metamorphic grade. By contrast, Rama Rao (1940) classified the Dharwar Supergroup into three groups - lower, middle and upper - on the basis of two conglomerate horizons. Taking a cue from Glikson's suggestion of two greenstone belts, Swami Nath et al (1976) and Radhakrishna and Vasudev (1977) divided the supracrustal rocks of the Dharwar 'system' into the Dharwar Supergroup and the Sargur Group. The decisive factor in their division was that the Dharwar Supergroup lies unconformably on the Peninsular Gneiss, whereas the Sargur Group is affected by and hence older than the gneisses. The 
supporting lines of evidence for this two-fold subdivision of the supracrustal rocks are contrasting metamorphic grade, structural complexity and lithological variation. In this paper dealing with the basement rocks in the Dharwar craton, we re-examine some of these proposals in the light of new findings.

\section{The supracrustal rocks}

The stratigraphic succession of the supracrustal rocks of the Dharwar craton is given in table 1. Whereas Rama Rao (1940), Pichamuthu (1982) and others consider that the Peninsular Gneiss evolved over an extended period of time and has therefore no stratigraphic significance, Swami Nath et al (1976) took the Peninsular Gneiss to separate their Sargur Group from the Bababudan Group of the Dharwar Supergroup. The division of the supracrustal rocks into Sargur and Dharwar on the strength of lithologic difference and metamorphic variation is not borne out by current evidence. The rocks of the Dharwar Supergroup comprise orthoquartzites, metapelites, carbonate rocks and banded manganese and iron formations. The quartzites are fuchsitic or muscovitic; biotite and chloritoid are present in the metapelites. Cummingtonite-grunerite, chlorite, biotite, siderite, ankerite, magnesioriebeckite and quartz constitute the mineral assemblages in the iron formations. Mafic and ultramafic igneous rocks are represented by amygdular or pillow lavas metamorphosed to actinolite-chlorite schists. In contrast with the low grade of metamorphism here, rocks of the so-called Sargur Group consist of the same quartzite-pelite-carbonate-BIF assemblages metamorphosed to a higher grade. The metapelites contain garnet, staurolite, kyanite and/or sillimanate; the carbonates comprise recrystallized cherty dolomite and calc-silicate rocks with diopside, tremolite and phlogopite. The BIF is recrystallized and consists of ortho- and clinopyroxene, almandine and magnetite.

Table 1. Stratigraphic succession of the Dharwar Supergroup of southern India.

\begin{tabular}{ll}
\hline $\begin{array}{l}\text { Upper Dharwar } \\
\text { (Chitradurga Group) }\end{array}$ & $\begin{array}{l}\text { Conglomerate, greywacke, } \\
\text { basalt, andesite, rhyolite, } \\
\text { banded iron formation, } \\
\text { banded manganese formation, } \\
\text { quartzite, pelite and carbonates, } \\
\text { metamorphosed to greensehist- } \\
\text { epidote amphibolite facies. }\end{array}$ \\
Middle Dharwar & $\begin{array}{l}\text { Conglomerate, quartzite, basalt, } \\
\text { rhyolite, pelite and banded iron } \\
\text { formation, metamorphosed to } \\
\text { greenschist-epidote amphibolite } \\
\text { facies. }\end{array}$ \\
& $\begin{array}{l}\text { Layered ultramafic-mafic complexes, } \\
\text { mafic volcanic rocks, quartzite, } \\
\text { pelite, banded iron formation and } \\
\text { carbonate rocks, metamorphosed to }\end{array}$ \\
& amphibolite-granulite facies. \\
\hline
\end{tabular}

* Sargur Group according to Swami Nath et al 1976. 
Manganiferous iron formations contain spessartite and Mn-pyroxene. The mafic sills and lavas are metamorphosed to amphibolite and pyribolites. Shorn of metamorphic impress, therefore, the rock types in the two divisions are almost identical (Srinivasan 1988). It has also been demonstrated (Raase et al 1986) that there is a gradual increase in metamorphic grade towards the south within all the supracrustal belts. It may be mentioned in this context that the amphibolite facies rocks of the Javanahalli schist belt (the largest belt supposedly belonging to the Sargur Group) is now considered by some of the proponents of the Sargur Group to belong to the Dharwar Supergroup (Ghosh Roy and Ramakrishnan, 1985).

It is now known that both ultramafic rocks and fuchsite quartzites occur in different parts of the supracrustal sequence irrespective of whether they are in the Dharwar

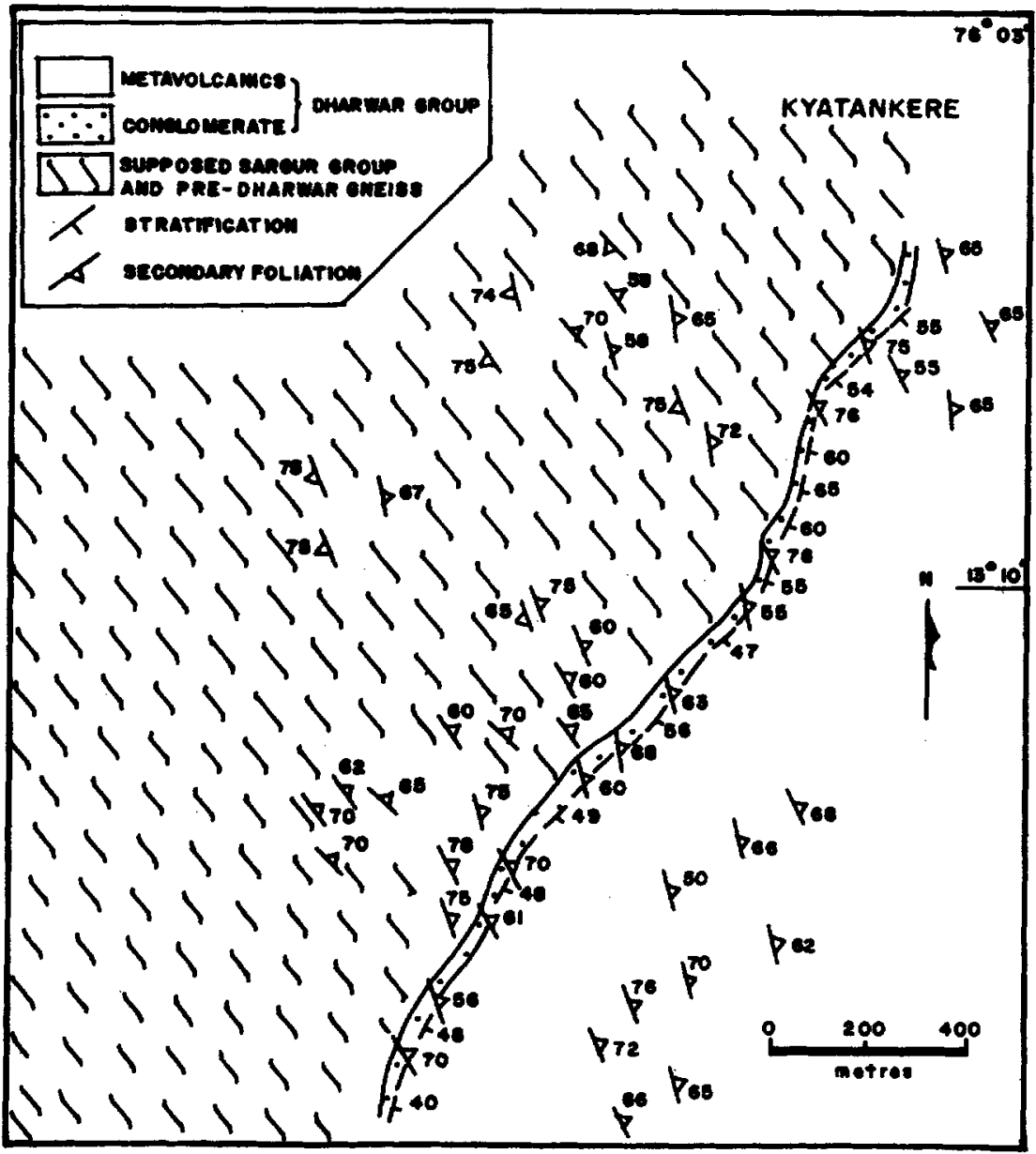

Figure 2. Map of the northern part of the Shigegudda schist belt, showing the continuity of the axial planar schistosity of the Dharwar Supergroup in the supposed Sargur Group and the pre-Dharwar Peninsular Gneiss (reproduced with permission from Quart. J. Geol. Min. Metal. Soc. Indiä, 58, 1986, figure 24). 
Supergroup or the supposed Sargur Group. Furthermore, detailed mapping in the Karigatta belt northeast of Mysore by Srinivasan (1988) has shown that the Sargur Group to the south and the Dharwar Supergroup to the north of a fault comprise quartzites and quartz pebble conglomerates, amphibolites with calc-silicate bands, and banded magnetite quartzite, with identical structures. Likewise, detailed mapping in the Honakere arm of the Nagamangala belt has shown that the $\mathrm{E}-\mathrm{W}$ trending Sargur rocks transected by the $\mathrm{N}-\mathrm{S}$ trending Dharwar rocks along a supposed angular unconformity actually represent different parts of a large open fold of the second generation.

As has been demonstrated in recent years (Mukhopadhyay 1986, and references therein; Naha et al 1986, 1990, 1991), the supracrustal rocks of the Dharwar Supergroup show three main episodes of deformation. The first deformation resulted in attenuated isoclinal folds with an axial planar cleavage $\left(\mathrm{DhF}_{1}\right)$. These have been involved in near-coaxial open folds $\left(\mathrm{DhF}_{1 \mathrm{a}}\right)$, which were affected in turn by non-coaxial upright folds $\left(\mathrm{DhF}_{2}\right)$ with axial planes striking nearly $\mathrm{N}-\mathrm{S}$. These upright folds vary widely in tightness with a common axial planar fabric. In some places all these structures have been affected by warps on nearly $\mathrm{E}-\mathrm{W}$ axial plane $\left(\mathrm{DhF}_{3}\right)$. So far no structural features distinct from and earlier than those in the Dharwar Supergroup have been recognized in the so-called Sargur Group.

The supposed angular unconformity between the Sargur and the Dharwar rocks around Shigegudda pointing to a separate status for the Sargur Group (Viswanatha et al 1982) has been shown to be untenable (Naha et al 1986, p. 234-236). This interpretation was based on the faulty premise that the angle between a deformationalmetamorphic fabric in one group and the depositional fabric in the other indicates an angular unconformity. As seen from figure 2, the deformational fabric is an axial planar cleavage affecting both the supposed Sargur and the Dharwar rocks (with refraction because of viscosity contrast in the rock types).

\section{Nature of the contact between the Peninsular Gneiss and the supracrustal rocks}

The supracrustal schists of the Dharwar Supergroup occur as five long, linear belts trending roughly NNW-SSE and many smaller enclaves within the Peninsular Gneiss (figure 1). The contact between the gneisses and the supracrustal rocks is marked in some places by quartz pebble conglomerate, notably in the southern border of the Bababudan belt and the western margin of the Chitradurga and Kudremukh belts. Conglomerate is absent in a major part of the gneiss-schist contact. Peninsular Gneiss is in contact with the. lower part of the Dharwar succession in the Nuggihalli and Holenarasipur areas (devoid of conglomerate), the middle part of the succession (Bababudan Group) in the Chikmagalur, Shigegudda and Kudremukh areas, and the upper part of the succession in the Chitradurga, Javanahalli and Dharwar regions. The fact that the gneiss-schist interface is at different stratigraphic levels in the Dharwar sequence implies that the Peninsular Gneiss has no stratigraphic significance.

As argued by Naha et al (1990), the supracrustal rocks of the Dharwar Supergroup (from the upper part of the succession represented by the Chitradurga Group at Javanahalli to the lowest part of the succession in the Nuggihalli and Holenarasipur belts) are extensively migmatized to give rise to the Peninsular Gneiss. 
4. Structural and migmatitic history of the Peninsular Gneiss and its significance

The Peninsular Gneiss is not only inhomogeneous in fabric but also varies in composition from tonalite through granodiorite to granite (Naha et al 1990). The mineral constituents of these gneisses is dependent on the nature of the Dharwar rocks which are migmatized. Thus, migmatization of amphibolites has resulted in biotite-epidote rich gneisses, whereas metapelites have muscovite-rich gneisses at their contact. The structural sequence found in the gneisses is identical with that in the Dharwar schists except for some small enclaves of basic material (figure 3). This implies that during the earliest deformation of the supracrustal rocks the gneisses reacted by ductile rather than by brittle deformation (figure 4 ).

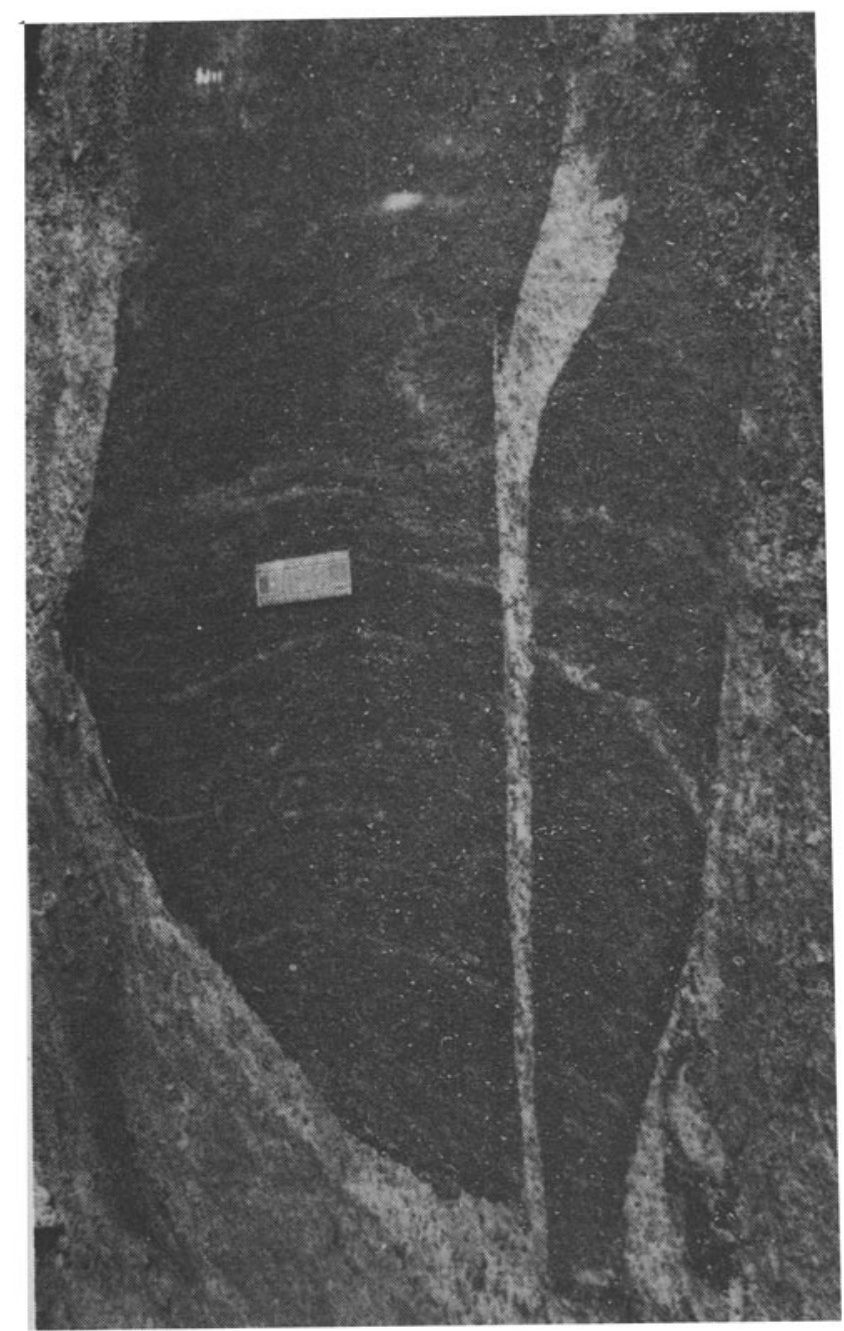

Figure 3. Migmatized dioritic gneiss enclave with isoclinal folds paralleled by foliation (parallel to scale) discordant with that in the gneissic host. A late quartzofeldspathic vein invading into the enclave has also developed a later $\left(\mathrm{DhF}_{2}\right)$ planar fabric in the lower part. Harobande quarry, Chikkaballapur. 


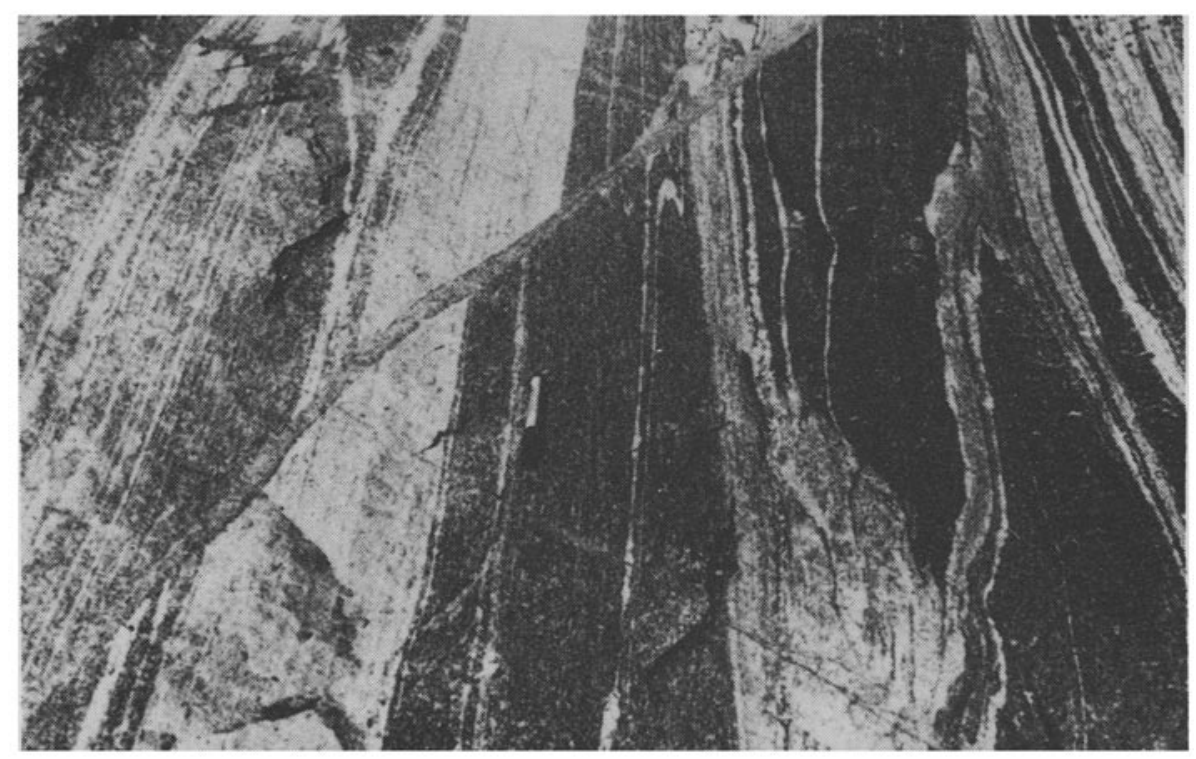

Figure 4. DhF , folding in migmatite with axial planes paralleled by banding (pencil parallel to it) having $\mathrm{N} 310^{\circ}$ strike. Pinch-and-swell structures parallel to axial planes, and diagonal shear fractures occupied by aplite noticeable. Hunasekatte quarry, east of Hosdurga.

As has been discussed in detail in Naha et al (1990), widespread migmatization took place during the first folding of the cover rocks. Although synkinematic migmatization during $\mathrm{DhF}_{2}$ folding is noticeable in a number of places (figures 3 and 5), faults and shear zones point to considerable brittle deformation during $\mathrm{DhF}_{2}$. Peninsular Gneiss in the core of an anticlinal structure around Hirekandavadi west of Chitradurga led Chadwick et al (1981) to suggest that the gneisses are the basement for the Dharwar Group. Detailed mapping around this area has shown that the gneisses occupy.the core of an antiformal syncline, the antiform being of $\mathrm{DhF}_{2}$ generation (figure 6; Naha and Srinivasan 1988). If the Peninsular Gneiss has any stratigraphic significance here, it has to be younger than the upper Dharwar (Chitradurga) rocks. But as mentioned above, the Peninsular Gneiss is demonstrably a composite gneiss formed by migmatization of supracrustal rocks in different phases at different stratigraphic levels. In that event, the gneisses in their present state cannot have any stratigraphic significance.

The following lines of evidence suggest that the Peninsular Gneiss was an original basement that has been extensively remobilized in different phases: (a) The presence of conglomerates only in some places at the gneiss-schist interface; (b) the similarity of folds in the gneisses and the Dharwar schists pointing to ductile deformation in the gneisses during folding in the supposed cover rocks; (c) the gneiss-schist interface straddling different levels of the Dharwar Supergroup; and (d) evidence of migmatization synkinematically with $\mathrm{DhF}_{1}$ (dominant) and $\mathrm{DhF}_{2}$ (less prominent) events. The remnants of this basement left in the wake of migmatization are traceable in the large number of enclaves several metres across throughout the gneissic terrane. These enclaves ranging in composition from migmatized amphibolite to more uniform tonalitic gneisses show a fabric which is at a high angle to, and earlier than, that in 


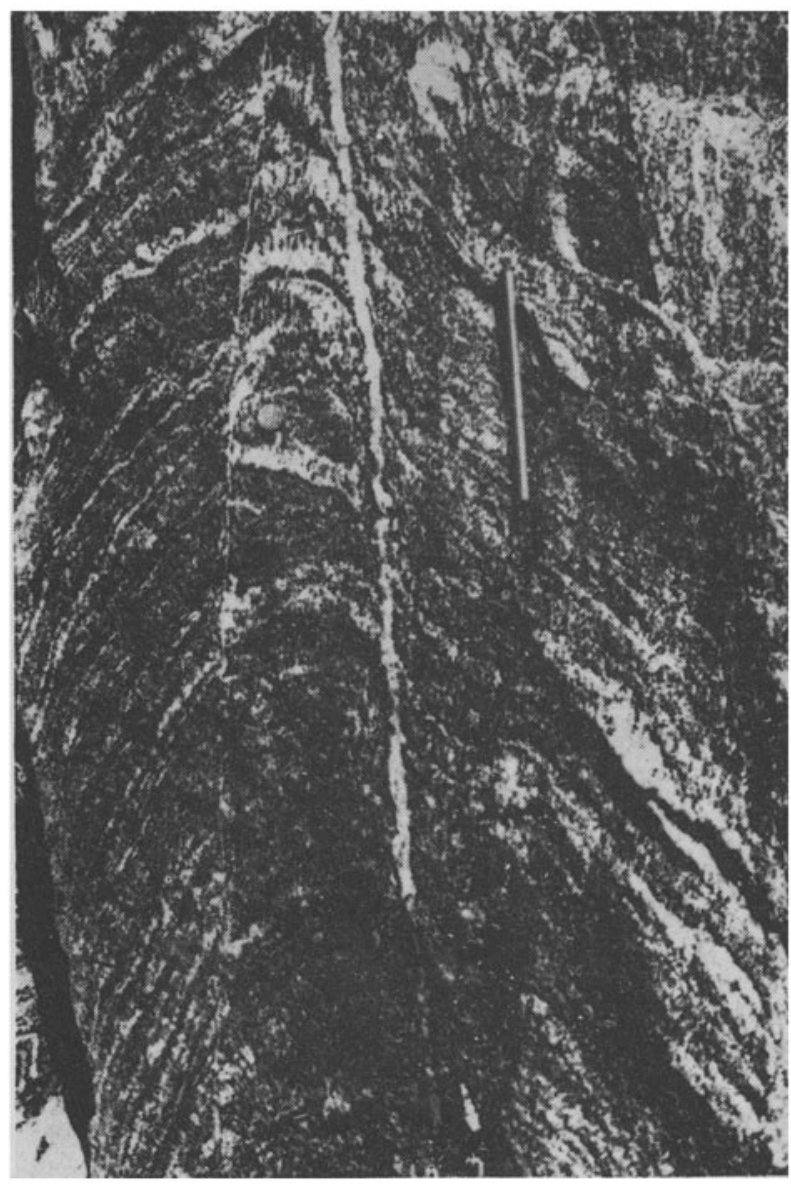

Figure 5. Foliation parallel to the axial planes of $\mathrm{DhF}_{2}$ fold (parallel to pencil) in Peninsular Gneiss. Bangalore University quarry.

the host gneisses. This earlier fabric $\left(\mathrm{DhF}_{*}\right.$ ) comprises compositional bands involved in isoclinal folding with a foliation parallel to the axial plane. Migmatization synkinematic with this folding is noticeable in a number of places. That these structures are earlier than the $\mathrm{DhF}_{1}$ fabric is seen in figure 3. Here the $\mathrm{DhF}_{*}$ axial plane and its associated foliation, which is almost at right angles to the $\mathrm{DhF}_{1}$ fabric in the central part, is gradually drawn into parallelism with that of the host gneisses in the margin. This type of enclave with discordant fabric is abundant in the Peninsular Gneiss terrane.

Boudins of amphibolite in the limbs of isoclinal folds of $\mathrm{DhF}_{*}$ phase involved in $\mathrm{DhF}_{1}$ folding of the host gneisses have also been observed (Naha et al 1990, figure 4). All these features point to at least one phase of deformation, metamorphism and migmatization in the original basement preceding the first deformation in the cover rocks $\left(\mathrm{DhF}_{1}\right)$, attendant with extensive synkinematic migmatization in the Peninsular Gneiss. The presence of gneissic pebbles in the conglomerates within the Dharwar succession corroborates this history. 


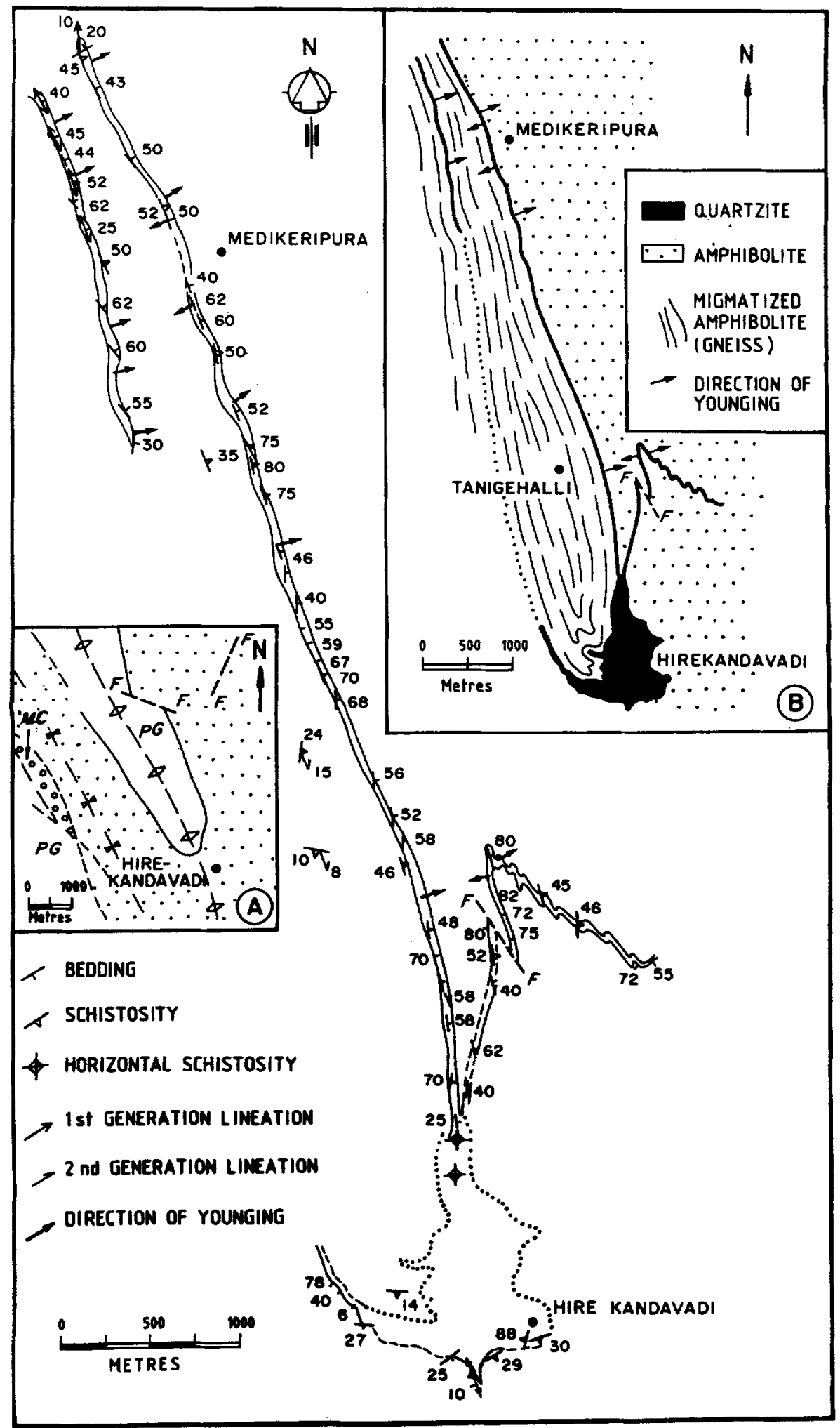

Figare 6. Detailed structural map of the Hirekandavadi area. Inset A - The Kandavadi 'anticline' after Chadwick et al 1981, figure 2c. PG = Peninsular Gneiss; dots = Bababudan Group; Open circles = Mayakonda conglomerate (MC), Chitradurga Group. Inset B Geological map of the Kandavadi area (see text for explanation). 


\section{Geochronological evidence on the nature and age of the basement}

From the foregoing discussion it is clear that the Peninsular Gneiss was not made in one stage, but 'remade' in different phases. Set against the background of the structural sequence, radiometric dating of the Peninsular gneisses with good structural control has been carried out. In order to determine the timing of the main events in the evolution of the Archaean basement in south India we have tried three lines of approach: (a) $\mathrm{Rb}-\mathrm{Sr}$ whole rock age determination of distinct components in the gneissic complex arrested at different stages of structural evolution; (b) $\mathrm{Rb}-\mathrm{Sr}$ whole rock isochron age determination of gneissic pebbles in the conglomerates of the Dharwar sequence; and (c) reconnaissance $\mathrm{Pb}-\mathrm{Pb}$ age determination of detrital zircons from metasedimentary rocks of the Dharwar Supergroup.

Although three phases of deformation $\left(\mathrm{DhF}_{1}, \mathrm{DhF}_{1 a}\right.$ and $\left.\mathrm{DhF}_{2}\right)$ have affected the gneisses extensively, there are some areas where the gneisses retain the $\mathrm{DhF}_{1}$ structures unaffected by recrystallization accompanying $\mathrm{DhF}_{2}$ deformation. Two such areas are the gneisses between Hassan and Gorur, and to the west of the Chitradurga schist belt east of Hosdurga (Hunasekatte). The thinly-banded gneisses in both these areas are tonalitic with the gneissosity striking nearly $\mathrm{E}-\mathrm{W}$, unlike the major part of the gneissic terrane where the strike is almost $\mathbf{N}-\mathbf{S}$. This gneissosity has been involved in $\mathrm{DhF}_{1}$ isoclinal folding with the axial planes also striking roughly $\mathrm{E}-\mathrm{W}$. Boudinage and pinch-and-swell structures in quartzofeldspathic veins parallel to gneissosity point to flattening normal to foliation in the buckle folds. In the Hunasekatte area, the $\mathrm{DhF}_{1}$ structures are practically undisturbed except for a set of prominent subvertical shear fractures (figure 4). By contrast, the Gorur gneiss has been involved in nearcoaxial $\mathrm{DhF}_{1 a}$ folding and non-coaxial gentle folding $\left(\mathrm{DhF}_{2}\right.$; Bhaskar Rao et al 1991, figures 3 and 4). There is however no recrystallization associated with the two later deformations.

The $\mathrm{Rb}-\mathrm{Sr}$ isotopic data for the Gorur and Hunasekatte gneisses based on cluster sampling are given in tables 2 and 3, and presented as isochrons in figures 7 and 8. These isochrons yield ages of $3204 \pm 30 \mathrm{Ma}(2 \sigma)$ and $3121 \pm 63 \mathrm{Ma}(2 \sigma)$ and initial $\mathrm{Sr}$ ratios $\left(\mathrm{Sr}_{i}\right)$ of $0.7011 \pm 0.0004(2 \sigma)$ and $0.7015 \pm 0.0006(2 \sigma)$ for Gorur and Hunasekatte suites, respectively. Our age result for Gorur gneiss is marginally younger than that $\left(3315 \pm 54 \mathrm{Ma}\right.$ with $\left.\mathrm{Sr}_{i}=0.7006 \pm 0.0003\right)$ reported by Beckinsale et al (1982) based on a much wider sampling. Since the migmatization resulting in the gneisses was synkinematic with the $\mathrm{DhF}_{1}$ deformation that has affected the supracrustal rocks, we tentatively interpret this age of $3100-3200 \mathrm{Ma}$ as the time of $\mathrm{DhF}_{1}$ deformation. In case the ages of the protoliths of the metavolcanic rocks in the supracrustal belts turn out to be younger than this age, we will have to take the first deformation here to be earlier than $\mathrm{DhF}_{1}\left(\mathrm{DhF}_{*}\right)$.

All three episodes of deformation are recorded in the Peninsular Gneiss of the Bangalore area (going as far as $60 \mathrm{~km}$ to the north near Chikkaballapur and $15 \mathrm{~km}$ to the south near Hulimavu), in contrast with the gneisses described above. Recrystallization of the main minerals is fairly common as indicated by a foliation marked by recrystallized biotite and inequant quartz parallel to the axial planes of the $\mathrm{DhF}_{2}$ folds (figure 5; Naha et al 1990, figure 11). Three sets of cluster samples from quarries near Chikkaballapur and Hulimavu yield the following results based on data given in tables 4 to 6 and shown in figures $9-11: 2512 \pm 84 \mathrm{Ma}$ with $\mathrm{Sr}_{i}$ of $0 \cdot 7010 \pm 0.0010$ for the Chikkaballapur gneissic host; $2511 \pm 64 \mathrm{Ma}$ with $\mathrm{Sr}_{i}$ of $0.7020 \pm 0.0009$ for 
Talle 2. Rb-Sr isotopic data for the Peninsular Gneiss, Gorur.

\begin{tabular}{llccc}
\hline Sample no. & $\begin{array}{c}\mathrm{Rb} \\
\text { (ppm) }\end{array}$ & $\begin{array}{c}\mathrm{Sr} \\
\text { (ppm) }\end{array}$ & $\begin{array}{c}{ }^{87} \mathrm{Rb} /{ }^{\circ 6} \mathrm{Sr} \\
\text { (atomic) }\end{array}$ & $\begin{array}{c}{ }^{87} \mathrm{Sr} /{ }^{86} \mathrm{Sr} \pm 2 \\
\text { (atomic) }\end{array}$ \\
\hline YBL-90 & 41 & 581 & 0.204 & $0.71062 \pm 6$ \\
PG87-137 & 23 & 82 & $0-823$ & $0.73977 \pm 8$ \\
YBL-78 & 38 & 105 & 1.056 & $0.75034 \pm 6$ \\
YBL-86 & 51 & 134 & 1.107 & $0.75091 \pm 14$ \\
PG87-143B & 33.35 & 69.42 & 1.398 & $0.76509 \pm 4$ \\
PG87-132 & $36 \cdot 19$ & $53-61$ & 1.971 & $0.79624 \pm 8$ \\
PG87-131 & 43 & 57 & $2 \cdot 183$ & $0.79977 \pm 6$ \\
YBL-68 & 52 & 42 & 3.634 & $0.87370 \pm 7$ \\
\hline
\end{tabular}

Table 3. Rb-Sr isotopic data for the Peninsular Gneiss, Hunasekatte.

\begin{tabular}{lcccc}
\hline Sample no. & $\begin{array}{c}\mathbf{R b} \\
\text { (ppm) }\end{array}$ & $\begin{array}{c}\mathrm{Sr} \\
\text { (ppm) }\end{array}$ & $\begin{array}{c}{ }^{87} \mathrm{Rb} /{ }^{66} \mathrm{Sr} \\
\text { (atomic) }\end{array}$ & $\begin{array}{c}{ }^{87} \mathrm{Sr} /{ }^{66} \mathrm{Sr} \pm 2 \\
\text { (atomic) }\end{array}$ \\
\hline $6 A$ & 54 & 289 & 0.541 & $0-72605 \pm 2$ \\
2 & 106 & 295 & 1.040 & $0.74874 \pm 4$ \\
1 & 110 & 263 & 1.210 & $0.75548 \pm 4$ \\
3 & 116 & 251 & 1.346 & $0.76217 \pm 4$ \\
6 & 104 & 211.8 & 1.427 & $0.76735 \pm 6$ \\
4 & 113.5 & 217.9 & 1.516 & $0.77003 \pm 4$ \\
\hline
\end{tabular}

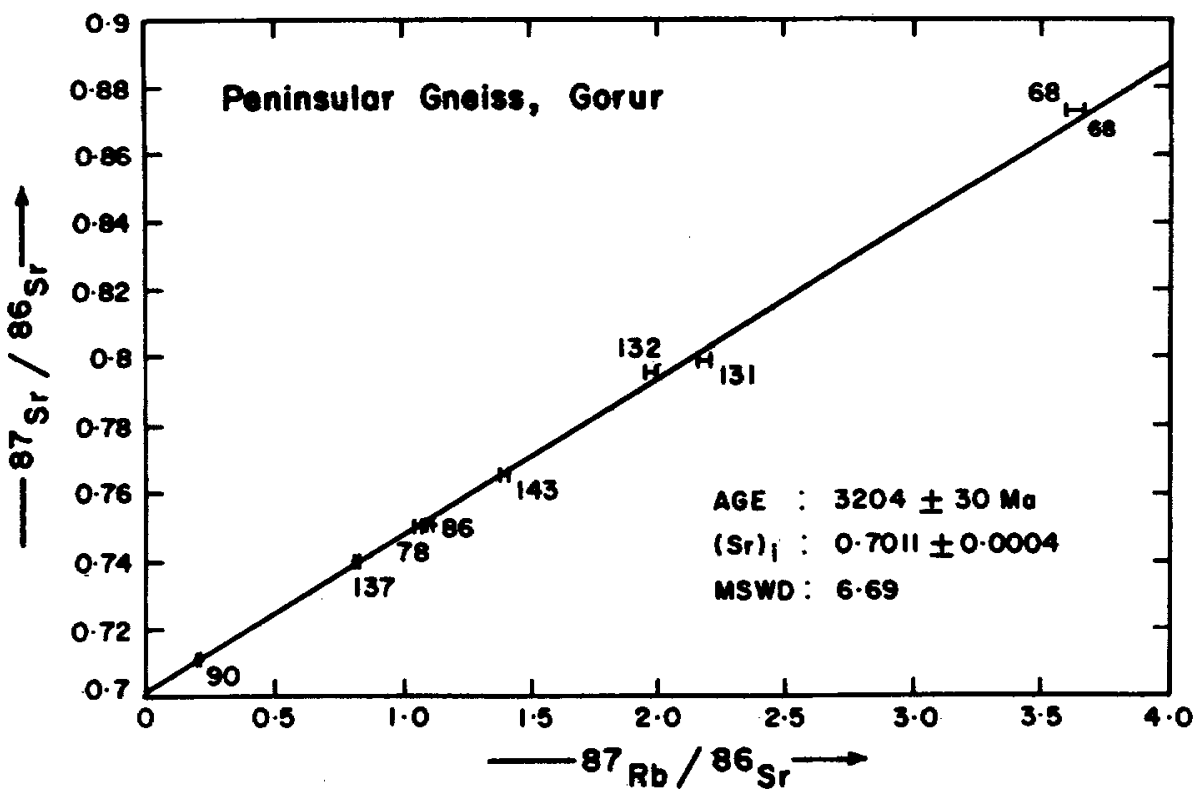

Figre 7. Rb-Sr isochron for the gneisses emplaced syntectonically with $\mathrm{DhF}_{1}$ event, Gorur.

Chikkaballapur gneissic enclaves; and $2730 \pm 92 \mathrm{Ma}$ with $\mathrm{Sr}_{i}$ of $0.7006 \pm 0.0010$ for the Hulimavu host gneiss. Since these gneisses preserve the folds of $\mathrm{DhF}_{1}$ phase and relicts of a still earlier deformational episode, we take the younger age of these gneisses at about $2600 \mathrm{Ma}$ as reflecting re-equilibration of the $\mathrm{Rb}-\mathrm{Sr}$ systematics in pre- 


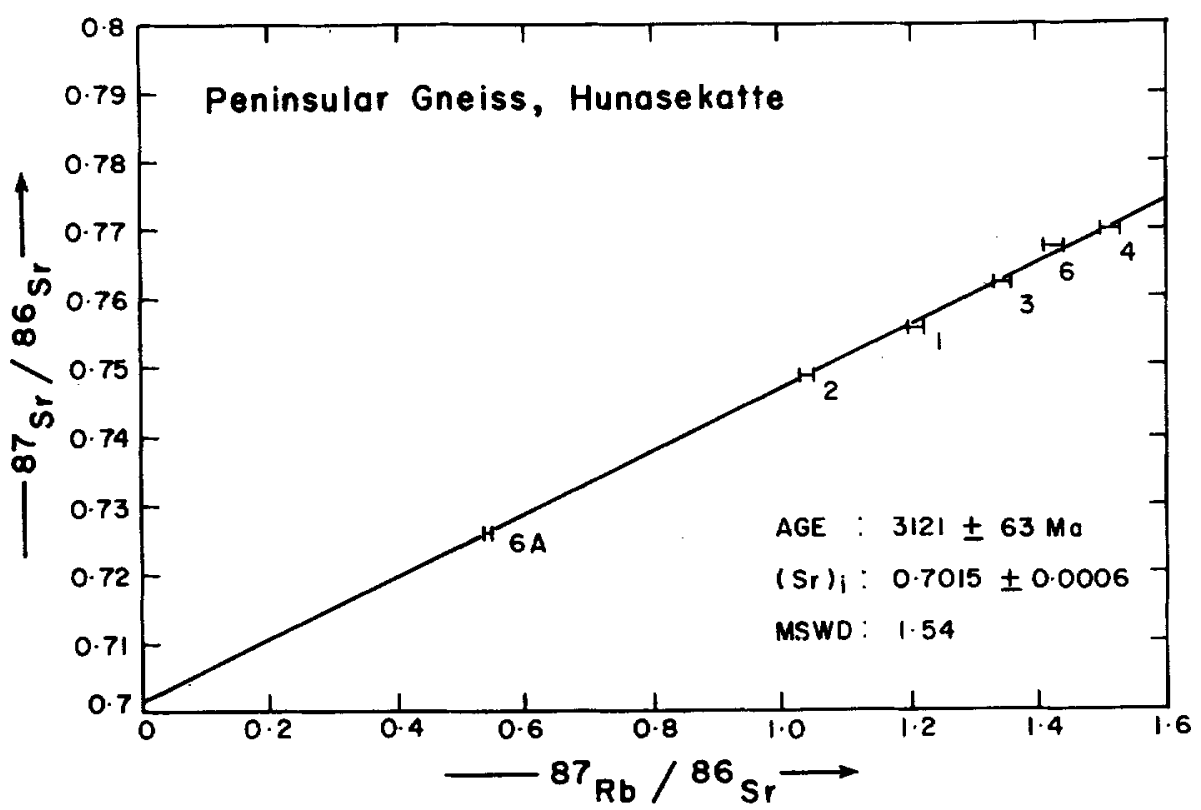

Figure 8. $\mathrm{Rb}-\mathrm{Sr}$ isochron for $\mathrm{DhF}_{1}$ gneisses from Hunasekatte quarry west of Chitradurga supracrustal belt, east of Hosdurga.

Table 4. Rb-Sr isotopic data for the Peninsular Gneiss, Chikkaballapur (Enclave).

\begin{tabular}{lrccc}
\hline Sample no. & $\begin{array}{c}\mathrm{Rb} \\
(\mathrm{ppm})\end{array}$ & $\begin{array}{c}\mathrm{Sr} \\
\text { (ppm) }\end{array}$ & $\begin{array}{c}{ }^{87} \mathrm{Rb} /{ }^{86} \mathrm{Sr} \\
\text { (atomic) }\end{array}$ & $\begin{array}{c}{ }^{87} \mathrm{Sr} /{ }^{86} \mathrm{Sr} \pm 2 \\
\text { (atomic) }\end{array}$ \\
\hline 87/PG/52 & 142.90 & $700 \cdot 10$ & 0.570 & $0.72263 \pm 3$ \\
87/PG/46 & 73.85 & 301.40 & 0.684 & $0.72644 \pm 4$ \\
87/PG/44 & 100.29 & 320.9 & 0.873 & $0.73472 \pm 5$ \\
87/PG/43 & 133.09 & 369.4 & 1.045 & $0.73697 \pm 3$ \\
87/PG/47 & 173.06 & 342.5 & 1.414 & $0.75223 \pm 3$ \\
87/PG/50 & 158.73 & 294.8 & 1.507 & $0.75684 \pm 4$ \\
\hline
\end{tabular}

Table 5. Rb-Sr isotopic data for the Peninsular Gneiss, Chikkaballapur (Host).

\begin{tabular}{|c|c|c|c|c|}
\hline Sample no. & $\begin{array}{c}\mathbf{R b} \\
(\mathrm{ppm})\end{array}$ & $\underset{\text { (ppm) }}{\mathrm{Sr}}$ & $\begin{array}{c}{ }^{87} \mathrm{Rb} /{ }^{86} \mathrm{Sr} \\
\text { (atomic) }\end{array}$ & $\begin{array}{l}{ }^{87} \mathrm{Sr} /{ }^{86} \mathrm{Sr} \pm 2 \\
\text { (atomic) }\end{array}$ \\
\hline $87 / \mathrm{PG} / 58$ & $101 \cdot 13$ & $288-4$ & $0-980$ & $0.73677 \pm 4$ \\
\hline $87 / P G / 62$ & 102.08 & 255.7 & $1 \cdot 159$ & $0.74304 \pm 2$ \\
\hline $87 / \mathrm{PG} / 61$ & 131.49 & $264 \cdot 5$ & 1.391 & $0.75051 \pm 3$ \\
\hline $87 / \mathrm{PG} / 67$ & $107 \cdot 10$ & 211.8 & 1.469 & $0.75515 \pm 2$ \\
\hline $87 / P G / 60$ & 144.89 & $247 \cdot 3$ & 1.616 & $0.75978 \pm 4$ \\
\hline $87 / P G / 63$ & $143 \cdot 74$ & 234.8 & 1.781 & $0.76614 \pm 4$ \\
\hline $87 / \mathrm{PG} / 59$ & $159 \cdot 3$ & 242 & 1.918 & $0.77026 \pm 3$ \\
\hline
\end{tabular}


Table 6. Rb-Sr isotopic data for the Peninsular Gneiss, Hulimavu (Host).

\begin{tabular}{|c|c|c|c|c|}
\hline Sample no. & $\underset{(\mathbf{p p m})}{\mathbf{R b}}$ & $\underset{(\mathrm{ppm})}{\mathrm{Sr}}$ & $\begin{array}{c}{ }^{87} \mathrm{Rb} /{ }^{86} \mathrm{Sr} \\
\text { (atomic) }\end{array}$ & $\begin{array}{c}{ }^{87} \mathrm{Sr} /{ }^{86} \mathrm{Sr} \pm 2 \\
\text { (atomic) }\end{array}$ \\
\hline PG/87/78 & $62 \cdot 10$ & $412 \cdot 2$ & $0-436$ & $0.71638 \pm 4$ \\
\hline$P G / 87 / 76$ & 57.81 & $277 \cdot 7$ & 0.604 & $0-72398 \pm 4$ \\
\hline PG/87/84 & 71.03 & $337 \cdot 3$ & 0.610 & $0.72521 \pm 5$ \\
\hline PG/87/80 & $101 \cdot 30$ & $385 \cdot 4$ & 0.762 & $0.73041 \pm 3$ \\
\hline PG/87/85 & $114-00$ & 374.4 & 0.883 & $0.73597 \pm 4$ \\
\hline PG/87/22 & $141 \cdot 26$ & $289-8$ & 1.417 & $0.75623 \pm 3$ \\
\hline
\end{tabular}

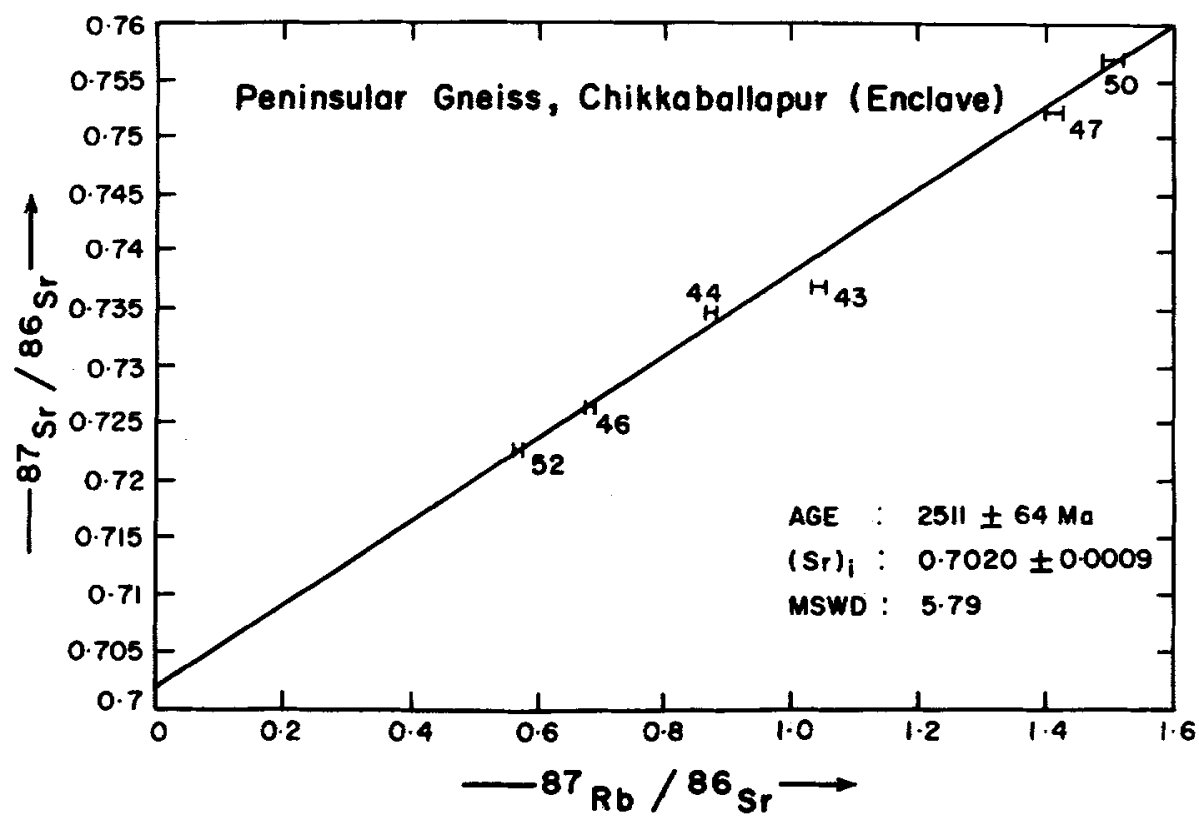

Figure 9. $R b-S r$ isochron for the migmatitic grieiss enclaves with relict $\mathrm{DhF}_{\text {abric. These }}$ enclaves occur in the Peninsular Gneiss evolved during $\mathrm{DhF}_{1}$ and $\mathrm{DhF}_{2}$. Whereas the earliest structural memory has been retained in the $\mathrm{DhF}_{*}$ fabric, the isotopic clock has been reset during the $\mathrm{DhF}_{2}$ deformation and migmatization; Chikkaballapur quarry, north of Bangalore.

existing gneiss during the $\mathrm{DhF}_{2}$ event. Significantly, neomineralization of biotite along the axial planes of the $\mathrm{DhF}_{2}$ folds is common in the enclaves also. Relevant in this context is Black's (1988) critical study of resetting of different isotopic systems ( $\mathrm{U}-\mathrm{Pb}$, $\mathrm{Rb}-\mathrm{Sr}$ and $\mathrm{Sm}-\mathrm{Nd}$ ); he concludes that isotopic resetting is facilitated by the development of a new penetrative fabric. The initial $\mathrm{Sr}$ ratios of the gneisses here ranging from 0.7006 to 0.7020 are distinctly lower than 0.7030 to which even the Gorur sample with the lowest ${ }^{87} \mathrm{Rb} /{ }^{86} \mathrm{Sr}$ ratios $(0-204)$ would have evolved from 3200 to $2600 \mathrm{Ma}$ ago. We therefore interpret that the $\mathrm{Sr}$ isotopic composition of these gneisses was not simply internally equilibrated during the $\mathrm{DhF}_{2}$ deformation event but lowered due to buffering of less radiogenic fluids of crustal or mantle origin. In this context 


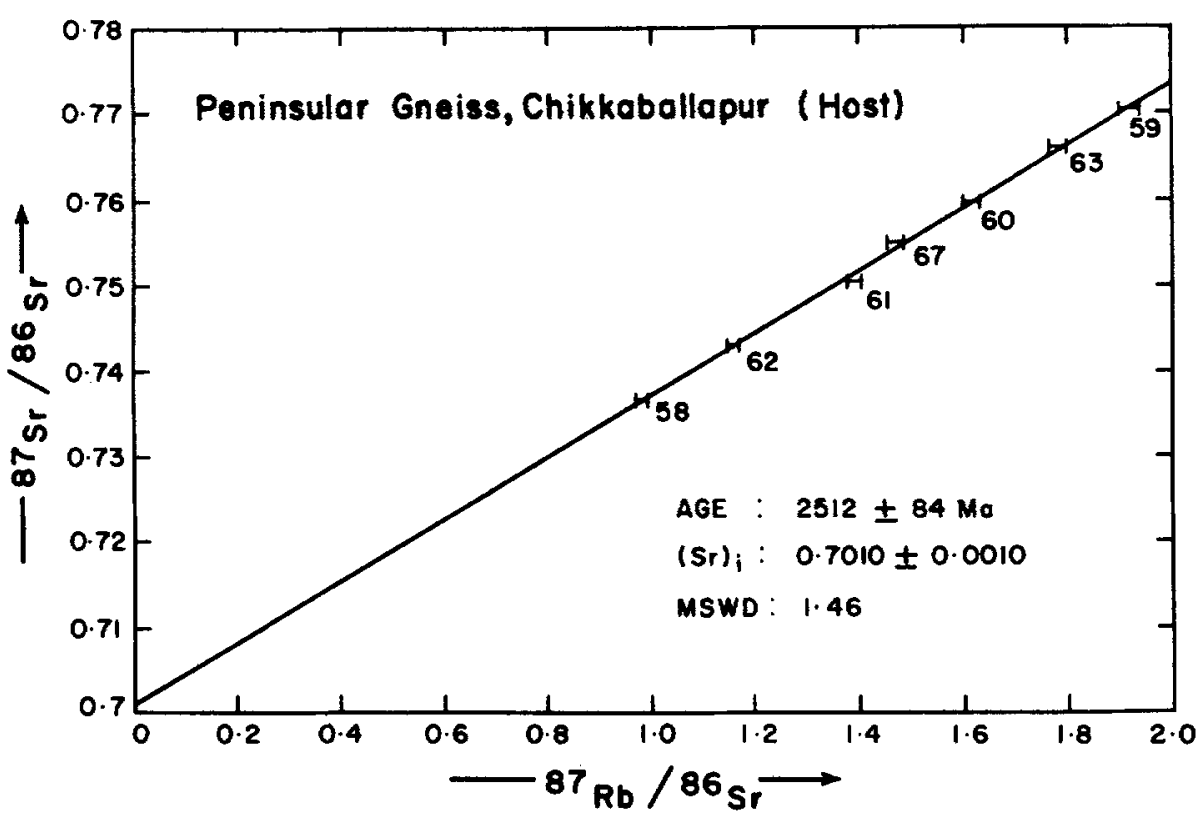

Figure 10. Rb-Sr isochron for the host gneisses in the Chikkaballapur quarry, evolved during $\mathrm{DhF}_{1}$ and $\mathrm{DhF}_{2}$.

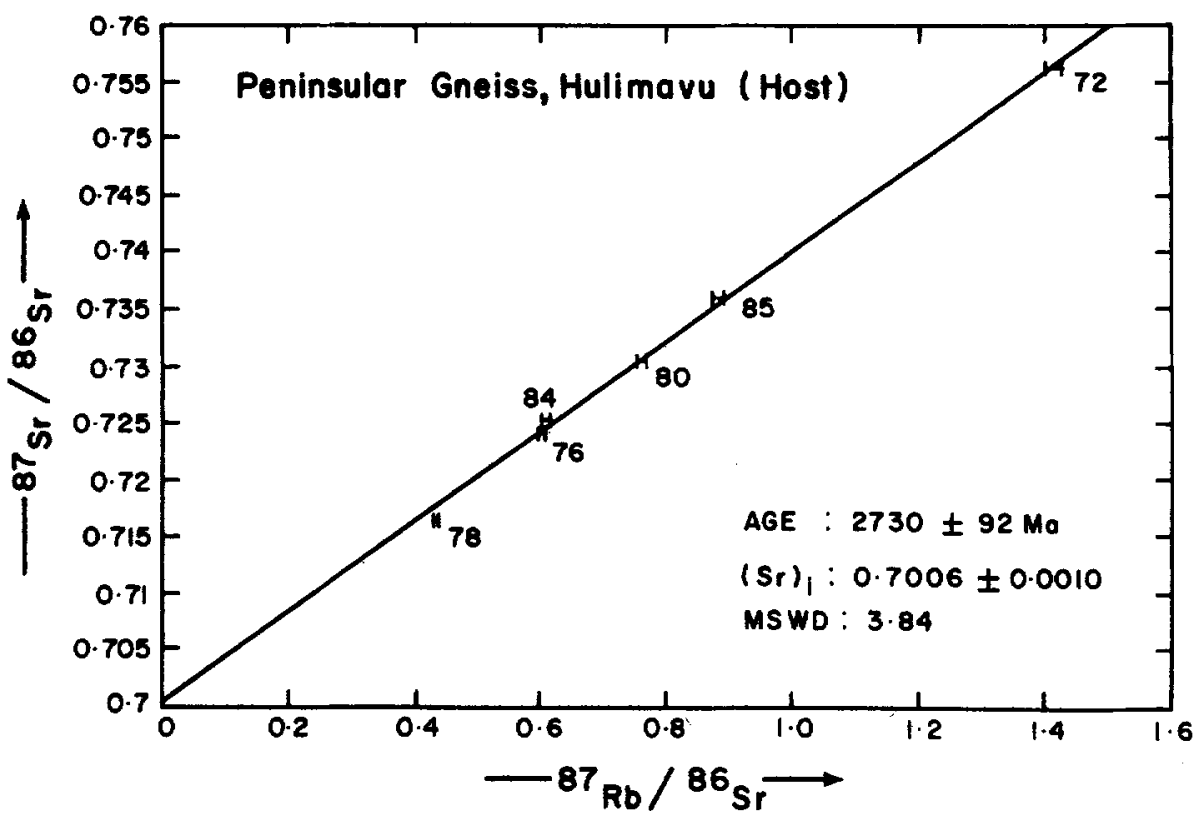

Figure 11. $\mathrm{Rb}-\mathrm{Sr}$ isochron for the host gneisses with $\mathrm{DhF}_{1}$ and $\mathrm{DhF}_{2}$ fabrics, Hulimavu quarry, south of Bangalore.

it is significant that granulite formation at $2600 \mathrm{Ma}$ ago near the study area has been attributed to large scale fluid infiltration (Newton 1992). We assign the age of $2600 \mathrm{Ma}$ to the $\mathrm{DhF}_{2}$ event. 
Gneissic pebbles in conglomerate horizons in the Dharwar succession are a potential source of information on the age of the basement rocks. One such horizon at the base of the Upper Dharwar (Chitradurga Group) is the Kaldurga conglomerate which is a polymictic conglomerate with pebbles, cobbles and boulders of tonalitic gneisses, migmatized amphibolites, metavolcanics, quartzites, limestones and BIF. Whereas the gneissic boulders and cobbles, which are often angular, suggest a nearby tonalitic source, the adjacent gneisses are more potassic (Pichamuthu 1935; Pichamuthu and Srinivasan 1983). This indicates that gneisses now extant in this area must have been modified from original tonalitic gneisses. Venkatasubramanian and Narayanaswamy (1974) reported a four point, somewhat imprecise, isochron corresponding to an age of $3310 \pm 134 \mathrm{Ma}$ and $\mathrm{Sr}_{i}=0.701 \pm 002$ for the Kaldurga gneiss pebbles. This result represented in fact the only evidence available prior to 1980 for the presence of rocks older than $3200 \mathrm{Ma}$ in the southern Indian shield. Despite the problem of interpretation of data from transported pebbles, the close agreement of this result with that of the Gorur and Hunasekatte rocks is striking. This, coupled with the field evidence that the Kaldurga pebbles must have had a nearby source, prompted us to analyze a larger set of Kaldurga pebbles with higher precision to see if they do conform to an isochron. Our data on samples taken from the core of large pebbles are given in table 7 and plotted in figure 12. The pebbles belong to two distinct geochemical suites - one with negative Eu anomaly and the other without this anomaly.

It can be seen that except for one sample, all others conform to a linear array. The rather high MSWD of 36 indicating slight failure of assumptions of isochron plot is not unexpected in this instance. While the isochron shown may not be rigorously interpretable in terms of a precise age and initial $\mathrm{Sr}$ composition for the provenance of the pebbles, it does show that the Rb-Sr systematics in the pebbles is consistent more with an age of about $2500 \mathrm{Ma}$ and not the much higher age of $3300 \mathrm{Ma}$ inferred by Venkatasubramanian and Narayanaswamy. The fact that the pebbles are welded to their matrix and contain recrystallized mica leads us to interpret our result as the time of nearly complete re-equilibration of $\mathrm{Sr}$ among nearby pebbles through the matrix during the $\mathrm{DhF}_{2}$ event. Our results on the $\mathrm{Rb}-\mathrm{Sr}$ systematics in the Kaldurga pebbles show that they do not represent the age of their provenance.

Search for the age of the original basement finally led us to dating of detrital zircons preserved in metasedimentary rocks of the Dharwar Supergroup. Zircon grains from quartzite and kyanite-muscovite schist from the lower Dharwar Supergroup in

Table 7. Rb-Sr isotopic data for gneiss pebbles in the Kaldurga conglomerate.

\begin{tabular}{lcccc}
\hline Sample no. & $\begin{array}{c}\mathbf{R b} \\
(\mathbf{p p m})\end{array}$ & $\begin{array}{c}\mathrm{Sr} \\
\text { (ppm) }\end{array}$ & $\begin{array}{c}{ }^{87} \mathbf{R b} /{ }^{66} \mathrm{Sr} \\
\text { (atomic) }\end{array}$ & $\begin{array}{c}{ }^{87} \mathrm{Sr} /{ }^{66} \mathrm{Sr} \pm 2 \\
\text { (atomic) }\end{array}$ \\
\hline KAL-M & 18.55 & 249.31 & 0.216 & $0.71856 \pm 3$ \\
KAL-D & 26.10 & 260.12 & 0.291 & $0.72220 \pm 3$ \\
KAL-G & 21.89 & 209.62 & 0.303 & $0.72116 \pm 4$ \\
KAL-B & & & 0.515 & $0.73045 \pm 3$ \\
KAL-N & 70.64 & 242.34 & 0.846 & $0.74219 \pm 3$ \\
KAL-T & 39.11 & 126.17 & 0.900 & $0.74025 \pm 3$ \\
KAL-R & 71.34 & 108.26 & 1.921 & $0.77961 \pm 3$ \\
KAL-L & 83.14 & 123.35 & 1.964 & $0.78126 \pm 4$ \\
\hline
\end{tabular}




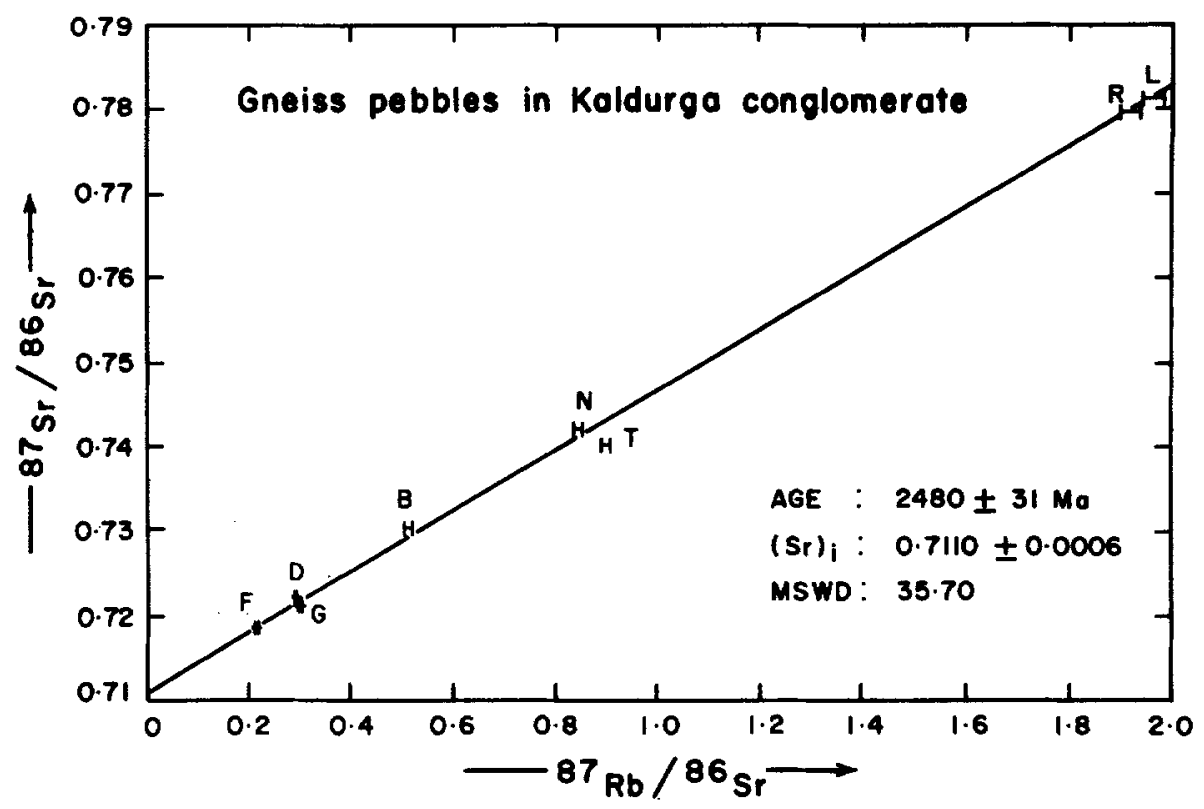

Figure 12. $\mathrm{Rb}-\mathrm{Sr}$ isochron for the pebbles of the Kaldurga conglomerate in the Dharwar sequence.

the Holenarasipur belt were separated. These are hyacinth red to brown, subrounded, clear, largely unzoned crystals. $\mathrm{Pb}-\mathrm{Pb}$ age of these zircon grains was determined by the direct evaporation technique on single grains (Kober 1987) by Prof. A Kroner in the geochronology laboratory at Mainz, Germany.

The histograms shown in figure 13 represent more than 80 lead isotope ratios measured from each grain at high evaporation temperatures and yield precise plateau ages of $3292 \pm 3 \mathrm{Ma}, 3309 \pm 5 \mathrm{Ma}$ and $3309 \pm 5 \mathrm{Ma}$ for the three grains. The excellent concordance of these ages indicates that they must be equal or very close to true primary crystallization ages of zircons.

Another set of 15 zircon grains separated from quartzites of the Bababudan Group (possibly from a slightly higher part of the succession) in the Bababudan and Chitradurga belts were analyzed in the Institute of Precambrian Geology and Geochronology, St. Petersburg, Russia. This was also carried out by the direct evaporation technique, but with the difference that each grain was evaporated from the mass spectrometric filament as a fine powder (table 8). The ages obtained in this way will be apparent ages which may not reflect the true crystallization age as closely as those obtained by the Kober technique. It can be seen from table 8 that although each age is subject to an analytical error of only about $10 \mathrm{Ma}$, there is a spread of ages between 2816 to $3188 \mathrm{Ma}$, with the older ages comparable with those obtained by whole-grain evaporation method.

The first order interpretation of these two sets of ages of detrital zircons is that the bulk of the oldest relict components in the supracrustal rocks are not older than $3300 \mathrm{Ma}$, which is only marginally older than the Rb-Sr ages of in situ tonalite gneiss such as from Gorur. The same conclusion comes from the recently reported SHRIMP $\mathrm{U}-\mathrm{Pb}$ ages (Nutman et al 1992) of detrital zircons from the older metasedimentary 


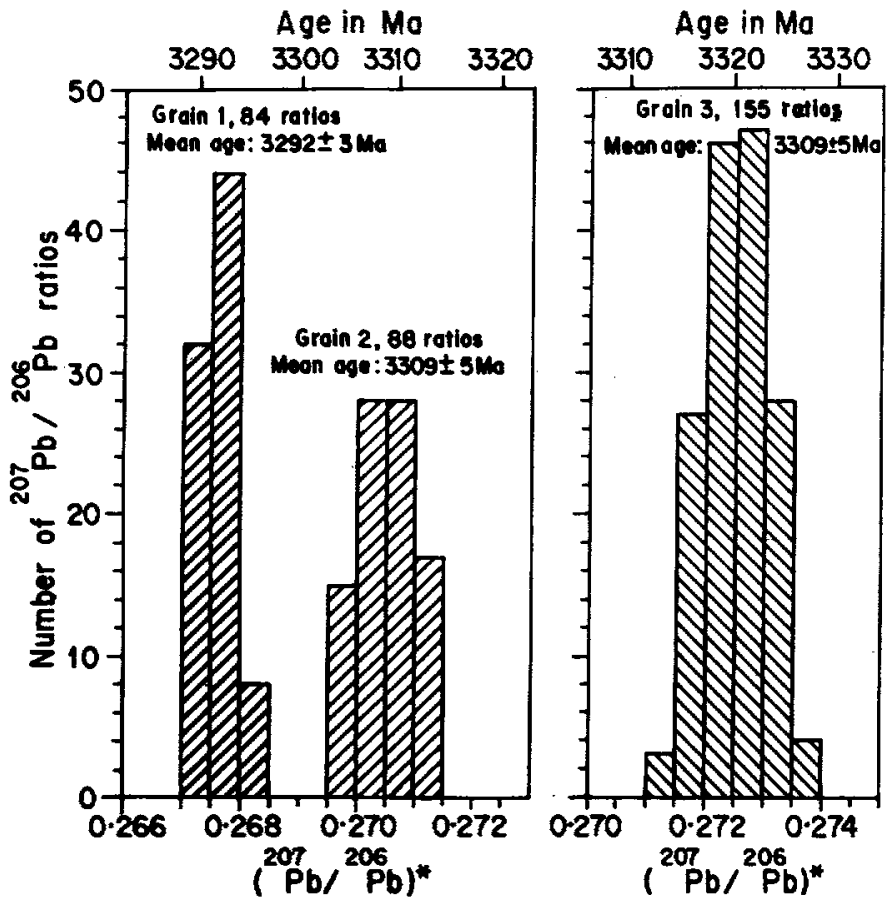

Figure 13. Histograms showing distribution of lead isotope ratios derived by evaporation of three detrital zircon grains from the metaquartzite samples from the lower part of the Dharwar sequence in the Holenarasipur supracrustal belt. The spectra plotted have been integrated from ratios as shown for each grain. Mean ages are given with 2 sigma error.

Table 8. Thermo ion emission $\mathrm{Pb}$ isotopic ages for the detrital zircons from the quartzites of the Bababudan Group.

\begin{tabular}{lccccc}
\hline Sample & ${ }^{207} \mathrm{~Pb} /{ }^{206} \mathrm{~Pb}$ & ${ }^{208} \mathrm{~Pb} /{ }^{206} \mathrm{~Pb}$ & ${ }^{204} \mathrm{~Pb} /{ }^{206} \mathrm{~Pb}$ & $\begin{array}{c}{ }^{207} \mathrm{~Pb} /{ }^{206} \mathrm{~Pb} \\
(\mathrm{rad} .)\end{array}$ & $\mathrm{T}(\mathrm{Ma})$ \\
\hline BBN-7-I & 0.25273 & 0.14226 & 0.00034 & 0.25058 & $3188 \pm 10$ \\
BBN-7-II & 0.22505 & 0.14588 & $0-00069$ & 0.21995 & $2980 \pm 10$ \\
BBN-7-III & 0.20409 & 0.08286 & 0.00035 & 0.20124 & $2835 \pm 10$ \\
BBN-3-I & 0.25426 & 0.14621 & 0.00167 & 0.24354 & $3143 \pm 10$ \\
BBN-3-II & 0.24259 & 0.13993 & $0-00091$ & 0.23645 & $3095 \pm 10$ \\
BBN-3-III & 0.20632 & 0.15949 & 0.00088 & 0.19915 & $2819 \pm 10$ \\
NKT-2 & 0.21316 & 0.14512 & 0.00020 & 0.21156 & $2917 \pm 15$ \\
NKT-1-I & 0.23872 & 0.09468 & 0.00003 & 0.23847 & $3109 \pm 10$ \\
NKT-1-II & 0.22143 & 0.09961 & $0-00044$ & 0.21809 & $2966 \pm 10$ \\
NKT-3-I & 0.23578 & 0.13714 & $0-00179$ & 0.22289 & $3000 \pm 10$ \\
NKT-3-II & 0.23186 & 0.13233 & $0-00017$ & 0.23062 & $3056 \pm 11$ \\
NKT-3-III & 0.19971 & 0.12511 & $0-00011$ & 0.19876 & $2816 \pm 10$ \\
NKT-11-I & 0.24800 & 0.11768 & 0.00018 & 0.24681 & $3164 \pm 8$ \\
NKT-11-II & 0.23719 & 0.11717 & 0.00036 & 0.23473 & $3083 \pm 9$ \\
\hline
\end{tabular}

BBN $=$ Bababudan Supracrustal belt; NKT $=$ Neralekatte, Chitradurga Supracrustal belt 
rocks in the Dharwar craton, with a majority of them in the range of 3130 to $3230 \mathrm{Ma}$. However, the presence of small pockets of still older relicts is indicated by the relatively few U-Pb zircon ages of $3580 \mathrm{Ma}$ from the supracrustal rocks (Nutman et al 1992), and fold relicts predating the $\mathrm{DhF}_{1}$ structures in the Peninsular Gneiss (Naha et al 1990).

The structural evidence combined with available geochronological data leads us to conclude that the Peninsular Gneiss of the southern Indian craton has evolved over nearly a billion years. The earliest phase of the Peninsular Gneiss appears to have formed as early as $3500 \mathrm{Ma}$ ago. Subsequently, this underwent reconstitution during two major tectonothermal episodes at about $3200 \mathrm{Ma}$ and $2600 \mathrm{Ma}$.

\section{Acknowledgements}

This work forms a part of the Indo-Russian Integrated Longterm Programme (ILTP) B-2-4 of the Department of Science and Technology, Government of India, and the Russian Academy of Sciences; and the Deep Continental Crust project of the National Geophysical Research Institute, Hyderabad. Thanks are due to Prof. Alfred Kroner of the University of Mainz, Germany, for carrying out $\mathrm{Pb}-\mathrm{Pb}$ dating of some of our samples. The authors are indebted to the Director, National Geophysical Research Institute, Hyderabad; the Director, Indian Institute of Technology, Kharagpur; and Prof. V K Gaur, Area co-ordinator of the ILTP, for encouraging this programme. $K$ Naha also acknowledges the financial support received for this study from the Jawaharlal Nehru Memorial Fund and the Council of Scientific and Industrial Research, Government of India. Critical review by Prof. Dhruba Mukhopadhyay and Dr John Myers led to considerable improvement of the manuscript.

\section{References}

Beckinsale R D, Reeves-Smith G, Gale N H, Holt R W and Thompson B 1982 Rb-Sr and Pb-Pb whole rock isochron ages and REE data for Archaean gneisses and granites, Karnataka state, South India (abstract); Indo-US workshop on Precambrians of Suuth India, Hyderabad 37-38

Bhaskar Rao Y J, Naha K, Srinivasan R and Gopalan K 1991 Geology, geochemistry and geochronology of the Archaean Peninsular Gneiss around Gorur, Hassan district, Karnataka, India; Proc. Indian Acad. Sci. (Earth Planet. Sci.) $100339-412$

Black L P 1988 Isotopic resetting of U-Pb zircon and Rb-Sr and Sm-Nd whole-rock systems in Enderby Island, Antarctica: Implications for the interpretation of isotopic data from polymetamorphic and multiply deformed terrains; Precambrian Res. 38 355-365

Chadwick B, Ramakrishnan M and Viswanatha M N 1981 The stratigraphy and structure of the Chitradurga region: An illustration of the cover-basement interaction in the late Archacan evolution of the Karnataka craton, Southern India; Precambrian Res. 16 31-54

Foote R B 1886 Notes on the geology of parts of Bellary and Anantapur districts; Rec. Geol. Surv. India 19 97-111

Ghosh Roy A K and Ramakrishnan M 1985 Stratigraphic status of the Javanahalli belt in the Archrean geology of Karnataka; J. Geol. Soc. India $26567-597$

Kober B 1987 Single zircon evaporation combined with $\mathrm{Pb}^{+}$emitter bedding for ${ }^{207} \mathrm{~Pb} /{ }^{206} \mathrm{~Pb}$ age investigations using thermal ion mass spectrometry and implications for zirconology; Contrib. Mineral. Petrol. 96 63-71

Mukhopadhyay D 1986 Structural pattern in the Dharwar craton; J. Geol. 94 167-186

Naha K and Srinivasan R 1988 Structure of the Kandavadi fold and its bearing on the basement problem in the Archaean Dharwar craton; Indian J. Earth Sci. 15 299-305 
Naha K. Srinivasan R and Naqui S M 1986 Structural unity in the Early Precambrian Dharwar tectonic province, Peninsular India; Q. J. Geol., Min. Metall. Soc. India 58 219-243

Naha K, Srinivasan R and Jayaram S 1990 Structural evolution of the Peninsular Gneiss - an Early Precambrian migmatitic complex from South India; Geol. Rundsch. 79 99-109

Naha K, Srinivasan R and Jayaram S 1991 Sedimentational, structural and migmatitic history of the Archaean Dharwar tectonic province, southern India; Proc. Indian Acad. Sci. (Earth Planet. Sci.) 100 413-433

Newton R C 1992 Charnockite alteration - evidence for $\mathrm{CO}_{2}$ infiltration in granulite facies metamorphism; J. Metamorphic Geol. 10 383-400

Nutman A P, Chadwick B, Ramakrishnan M and Viswanatha M N 1992 SHRIMP U-Pb ages of detrital zircon in Sargur supracrustal rocks in western Karnataka, southern India; J. Geol. Soc. India 39 367-374

Pichamuthu C S 1935 The conglomerates and grits of Kaldurga, Mysore; Proc. Indian Acad. Sci. 2234

Pichamuthu C S 1982 Schist-gneiss relation in Dharwar craton; Curr. Sci. 51 165-178

Pichamuthu C S and Srinivasan R 1983 A billion year history of the Dharwar craton ( 3200 to $2100 \mathrm{~m} . y$. ago); Geol. Soc. India Mem. 4 121-142

Raase P, Raith M, Ackermand D and Lal R K 1986. Progressive metamorphism of mafic rocks from greenschist to granulite facies in the Dharwar craton of South India; J. Geol. 94 261-282

Radhakrishna B P and Vasudev V N 1977 The early Precambrian of the southern Indian shield; J. Geol. Soc. India $8525-541$

Rama Rao B 1940 The Archaean complex of Mysore; Bull Mysore Geol. Dept. 17 1-101

Smeeth W F 1916 Outline of the geological history of Mysore; Bull. Dept. Mines \& Geology, Mysore State $61-21$

Srinivasan R 1988 Present status of the Sargur Group of the Archaean Dharwar craton, South India; Indian J. Geol. 60 57-72

Swami Nath J, Ramakrishnan M and Viswanatha M N 1976 Dharwar Stratigraphic model and Karnataka craton evolution; Rec. Geol. Surv. India. 107 149-175

Taylor P N, Chadwick B, Friend C R L, Ramakrishnan M, Moorbath S and Viswanatha M N 1988 New age data on the geological evolution of Southern India (abstract); J. Geol. Soc. India, 31 155-157

Venkatasubramanian V S and Narayanaswamy R 1974 Ages of gneissic pebbles in Kaldurga conglomerates; J. Geol. Soc. India 15 318-319

Viswanatha M N, Ramakrishnan M and Swami Nath J 1982 Angular unconformity between Sargur and Dharwar supracrustals in Shigegudda, Karnataka craton; J. Geol. Soc. India 23 85-89 